\title{
MYCOPLASMAS ISOLATED FROM THE RESPIRATORY TRACT OF CATTLE IN BOSNIA AND HERZEGOVINA
}

\author{
Maksimović Zinka, Rifatbegović Maid* \\ Department of Microbiology and Infectious Diseases, Veterinary Faculty, University of Sarajevo, \\ Zmaja od Bosne 90, 71000 Sarajevo, Bosnia and Herzegovina
}

* Corresponding author: Rifatbegović Maid, Department of Microbiology and Infectious Diseases, Veterinary Faculty, University of Sarajevo, Zmaja od Bosne 90, 71000 Sarajevo, Bosnia and Herzegovina. Phone: 0038733617 370,E-mail: maid.rifatbegovic@vfs.unsa.ba

Historial del artículo:

Recibido: 17 octubre 2012

Aceptado: 3 diciembre 2012

\section{RESUMEN}

Este trabajo presenta los resultados del aislamiento de micoplasmas respiratorios en ganado vacuno de Bosnia Herzegovina entre los años 2002 y 2010. Se analizaron 328 hisopos nasales y 59 muestras de pulmón remitidas para el aislamiento de micoplasmas. Un total de 27 muestras resultaron positivas (6.9\%). Se identificó la presencia de $M$. bovis en 8 hisopos y 2 pulmones, mientras que $M$. bovirhinis $(\mathrm{n}=4)$ y Acholeplasma $\mathrm{sp} .(\mathrm{n}=1)$ se detectaron en hisopos nasales. Doce aislamientos de micoplasma (44.4\%) no pudieron ser identificados con los métodos habituales de diagnóstico.

Keywords: Ganado bovino, aparato respiratorio, micoplasmas, M. bovis, M. bovirhinis.

\begin{abstract}
This study represents Mycoplasma species isolated from the respiratory tract of cattle in Bosnia and Herzegovina between 2002 and 2010. A total of 328 nasal swabs and 59 lung samples were submitted for isolation of mycoplasmas. Mycoplasmas were isolated from 27 samples (6.9\%). M. bovis was recovered from eight nasal swabs and two lungs, while M. bovirhinis $(\mathrm{n}=4)$ and Acholeplasma sp. $(\mathrm{n}=1)$ were detected only in nasal swabs. Twelve mycoplasma isolates were unidentified (44.4\%).
\end{abstract}

Keywords: cattle, respiratory system, mycoplasmas, M. bovis, M. bovirhinis. 


\section{INTRODUCTION}

Bovine respiratory disease is the most common illness affecting housed cattle worldwide. Mycoplasmas cause some of the most serious and economically most costly respiratory diseases of cattle. Contagious bovine pleuropneumonia, caused by $M$. mycoides subsp. mycoides small colony (SC) is the only bacterial disease classified by the Office International des Epizooties as a list A disease (Nicholas et al., 2008). Mycoplasma bovis is the most pathogenic bovine mycoplasma in the parts of the world that are free of contagious bovine pleuropneumonia (Nicholas et al., 2003). Other mycoplasmas involved in bovine respiratory disease include $M$. dispar, $M$. bovigenitalium, M. bovirhinis, M. canis, M. alkalescens and Ureaplasma diversum (Nicholas et al., 2008). Clinical respiratory diseases are common in Bosnia and Herzegovina (B\&H) herds. The relative absence of disease control measures contributes the involvement of mycoplasmas in respiratory disease. This study represents Mycoplasma species isolated from the respiratory tract of cattle population in $\mathrm{B} \& \mathrm{H}$ between 2002 and 2010.

\section{MATERIAL AND METHODS}

A total of 328 nasal swabs and 59 lung samples were collected from cattle from various regions in $\mathrm{B} \& \mathrm{H}$. The nasal swabs were obtained from 221 animals showing no signs of disease and 107 with clinical signs of respiratory infection. Lung samples were collected only from cattle with clinical signs of respiratory infection. All samples were cultured in liquid and solid media (Thiaucourt et al., 1996) and incubated in a $95 \% \mathrm{~N}_{2}$ and $5 \% \mathrm{CO}_{2}$ humidified atmosphere at $37^{\circ} \mathrm{C}$. Preliminary identification of the isolates was performed using culture morphology (Gourlay et al., 1983) and biochemical examination (sensitivity to digitonin, fermentation of glucose, hydrolysis of arginine, phosphatase activity, film and spots

Table 1. Oligonucleotide primers used for identification

\begin{tabular}{|c|c|c|}
\hline Primers (references) & Primer design & Fragment size \\
\hline \multirow{2}{*}{$\begin{array}{l}\text { Mollycutes-Mycoplasma } \\
\text { group (van Kuppeveld et al., } \\
\text { 1994) }\end{array}$} & $\begin{array}{l}\text { GPO-3 } \\
\text { 5'-GGGAGCAAACAGGATTAGATACCCT-3, }\end{array}$ & \multirow{2}{*}{$280 \mathrm{bp}$} \\
\hline & $\begin{array}{l}\text { MGSO: } \\
\text { 5'-TGCACCATCTGTCACTCTGTTAACCTC-3' }\end{array}$ & \\
\hline \multirow[t]{2}{*}{$\begin{array}{l}\text { M. bovirhinis (Hirose et al., } \\
\text { 2001) }\end{array}$} & $\begin{array}{l}M b r \text { F } \\
\text { 5'-GCT GAT AGA GAG GTC TAT CG-3, }\end{array}$ & \multirow{2}{*}{316 bp } \\
\hline & $\begin{array}{l}M b r \text { R } \\
\text { 5'-ATT ACT CGG GCA GTC TCC-3' }\end{array}$ & \\
\hline \multirow[t]{2}{*}{$\begin{array}{l}\text { M. bovis (Subramaniamet al., } \\
\text { 1998) }\end{array}$} & $\begin{array}{l}\text { MBOUVRC2-L } \\
\text { 5'-TTACGCAAGAGAATGCTTCA-3', }\end{array}$ & \multirow{2}{*}{$1626 \mathrm{bp}$} \\
\hline & $\begin{array}{l}\text { MBOUVRC2-R } \\
\text { 5'-TAGGAAAGCACCCTATTGAT-3' }\end{array}$ & \\
\hline \multirow[t]{2}{*}{ M. bovis (Pinnow et al., 2001) } & $\begin{array}{l}M b \text { F } \\
5 \text { '- TTT TAG CTC TTT TTG AAC AAA T - 3, }\end{array}$ & \multirow{2}{*}{1911 bp } \\
\hline & $\begin{array}{l}M b \text { R } \\
\text { 5' - GGC TCT CAT TAA GAA TGT C - 3, }\end{array}$ & \\
\hline
\end{tabular}


Table 2. Biochemical characteristics of non-identified mycoplasmas

\begin{tabular}{|c|c|c|c|c|c|c|}
\hline \multirow{2}{*}{ Strains } & \multicolumn{7}{|c|}{ Tests } \\
\cline { 2 - 7 } & $\begin{array}{c}\text { Typical colony } \\
\text { type }\end{array}$ & Digitonin & Glucose & Arginine & Phosphatase & Film\&Spot \\
\hline $138 / 09$ & + & + & - & - & + & + \\
\hline $139 / 09$ & + & + & - & - & + & + \\
\hline $140 / 09$ & + & + & - & - & + & + \\
\hline $07 / 10$ & + & + & - & - & - & + \\
\hline $107 / 08$ & + & + & + & - & - & - \\
\hline $105 / 08$ & + & + & - & - & - & - \\
\hline $106 / 08$ & + & + & - & - & + & - \\
\hline $01 / 10$ & + & + & - & - & + & - \\
\hline $06 / 10$ & + & + & - & - & Not tested & - \\
\hline $196 / 03$ & + & + & - & - & - & - \\
\hline $09 / 10$ & + & + & - & + & - & - \\
\hline $135 / 09$ & - & + & + & - & & + \\
\hline
\end{tabular}

production) (Poveda 1998). Growth inhibition test (GIT) was performed according Poveda and Nicholas (1998) with antisera specific for M. bovis, M. bovirhinis and M. arginini. Final identification of the isolates was performed by polymerase chain reactions (PCR). PCR assays for M.bovis, M. bovirhinis and Mollicutes (Table 1) were performed in a GeneAmp PCR System 2700 thermal cycler (Applied Biosystems), in a total volume of $25 \mu 1$.

DNA samples were prepared as described by Tola et al. (1997) with some modifications. Briefly, $200 \mathrm{ml}$ of each isolate were incubated for $10 \mathrm{~min}$ at room temperature with $100 \mathrm{ml}$ of denaturation buffer $(0.5 \mathrm{M} \mathrm{NaOH}, 1.5 \mathrm{M}$ $\mathrm{NaCl}$ ) and then for a further $10 \mathrm{~min}$ at room temperature with $40 \mu 1$ of silica particles suspended in $900 \mu 1$ of lysis buffer (10.12 $\mathrm{M}$ guanidine isothiocyanate, $0.1 \mathrm{M}$ Tris- $\mathrm{HCl}$, $\mathrm{pH}$ 6.4, 0.11 M EDTA, pH 8.0, 2.6\% Triton $\mathrm{X}-100$ ). After centrifugation at $12,000 \mathrm{x} \mathrm{g}$ for $15 \mathrm{~s}$, the pellet was washed twice with washing buffer (10.12 M guanidine isothiocyanate, 0.1
M Tris- $\mathrm{HCl}, \mathrm{pH}$ 6.4), twice with $70 \%$ ethanol and once with acetone. The dried pellet was then resuspended in $100 \mathrm{~m} 1$ of TE buffer (10 $\mathrm{mM}$ Tris- $\mathrm{HCl}, \mathrm{pH}$ 8.0, 1 mM EDTA, $\mathrm{pH}$ 8.0), heated at $56{ }^{\circ} \mathrm{C}$ for $10 \mathrm{~min}$, briefly vortexed and centrifuged at $12,000 \mathrm{x} \mathrm{g}$ for $2 \mathrm{~min}$. 5 $\mu 1$ of supernatant were added to the reaction mixture for amplification. Amplified samples were analysed by electrophoresis in a 1.5 per cent agarose gel. The gel was then stained with ethidium bromide and examined under a transilluminator (Vilber Lourmat).

\section{RESULTS}

A total of 27 samples were positive for mycoplasmas (6.9\%). Mycoplasmas were isolated from 22 of the 328 nasal swabs and five of the 59 lung samples. In accordance to animal health status, mycoplasmas were found in 7 (3.16\%) of 221 nasal swabs from asymptomatic animals and 15 (14\%) from symptomatic animals. M. bovis was recovered 
from ten samples $(37 \%)$, and most strains $(\mathrm{n}=8)$ were isolated from nasal swabs. All M. bovis strains were isolated from the symptomatic cattle. M. bovirhinis was identified in $14.8 \%$ nasal swabs from asymptomatic cattle and one nasal swab was positive for Acholeplasma sp. $(3.7 \%)$. Twelve mycoplasma isolates were identified by PCR only to the level of class (Mollicutes) (Table 2).

\section{DISCUSSION}

M. bovis was the most common mycoplasma species isolated during the research period. In this study, it was recovered only from cattle showing clinical signs of respiratory infection, although the presence of $M$. bovis in the upper respiratory tract of healthy cattle has been reported (Feenstra et al., 1991; Ter Laak et al., 1992). The identification rate of M. bovis in the present study (37\% of the isolates) is lower than that reported by Ayling et al. (2004) and Chazel et al. (2010), who obtained isolation rates of $52 \%$ and $55 \%$ of the isolates, respectively. The relatively low isolation rate in this study may be associated with the use of antibiotic therapy before sampling, or clinical status of the cattle (Thomas et al., 2002). The most common antibiotics used in $\mathrm{B} \& \mathrm{H}$ against respiratory infection of cattle are fluoroquinolones and tetracyclines. The both groups of antibiotics are well known as inhibitors of mycoplasmas and that additionally support possibilities of their negative impact to isolation process in this study. Failure to identified two isolate of $M$. bovis $(01 / 02$ and $14 / 10)$ in this study by GIT could be conducted with antigen variability of this species. Interesting finding is that arthritis or mastitis caused by this mycoplasma was not reported during this research. It is particularly important for mastitis which is one of the most serious and economically most costly diseases of dairy cattle worldwide (Gonzalez et al., 2003). Other pathogenic mycoplasmas were not identified, but one strain showed cultural and biochemical characteristics typical for M. dispar. For this species it has been shown to cause pneumonia following experimental infection, although the disease produced is not severe (Nicholas et al., 2008). In contrast to $M$. bovis, $M$. bovirhinis was isolated only from cattle showing no signs of disease. This mycoplasma can be found in the upper and lower respiratory tracts of both healthy and diseased cattle. It is not believed to be a primary pathogen but may exacerbate existing disease conditions caused by other pathogens (Nicholas et al., 2008).

The presence of $M$. bovis in animals with clinical respiratory disease provides the opportunity for this organism to be spread and to cause severe disease, and underscores the need to develop control measures to combat respiratory diseases in cattle. Based on the results obtained in this study, we believe that most important control measures that should be used in $\mathrm{B} \& \mathrm{H}$ are quarantine and control of all new animals, prior their introduction in the farm. Also, new cattle should be bought in the areas free of M. bovis. Further studies are required to identify other mycoplasma isolates.

\section{ACKNOWLEDGEMENTS}

This work was partly supported by a financial grant from the government of Kanton Sarajevo (Contract No 11-14-21161.1/07).

\section{REFERENCES}

\section{AYLING R.D., BASHIRUDDIN S.E.,} NICHOLAS R.A. 2004. Mycoplasma species and related organisms isolated from ruminants in Britain between 1990 and 2000. Vet. Rec. 155: 413-416.

CHAZEL M., TARDY F., LE GRAND D., DIDIER C., POUMARAT F. 2010. Mycoplasmoses of ruminants in France: recent data from the national surveillance network. BMC Vet. Res. 6: 32. 
FEENSTRA A., BISGAARD MADSEN E., FRIIS N.F., MEYLING A., AHRENS P. 1991. A field study of Mycoplasma bovis infection in cattle. J. Vet. Med. B. 38 (1-10): 195-202.

GONZALEZ R.N., WILSON D.J. 2003. Mycoplasmal mastitis in dairy herds. Vet. Clin. North. Am. Food. Anim. Pract. 19: 199-221.

GOURLAY N.R., HOWARD J.C. 1983. Recovery and identification of bovine mycoplasmas. In: Tully J.,G., Razin S., (Eds.) Methods in Mycoplasmology. Diagnostic Mycoplasmology. Vol II, Academic Press, New York: 81-89.

HIROSE K., KAWASAKI Y., KOTANI K., TANAKA A., ABIKO K., OGAWA H. 2001. Detection of mycoplasma in mastitic milk by PCR analysis and culture method. J. Vet. Med. Sci. 63(6):691-693.

NICHOLAS R., AYLING R., MCAULIFFE

L. 2008. Bovine Respiratory Disease. In: Nicholas R. et al. (Eds.) Mycoplasma Diseases of Ruminants. Cab International: 132-168.

NICHOLAS R.A., AYLING R.D. 2003. Mycoplasma bovis: disease, diagnosis, and control. Res. Vet. Sci. 74 (2):105-112.

PINNOW C.C, BUTLER J.A., SACHSE K., HOTZEL H., TIMMS L.L., ROSENBUSCH R.F. 2001. Detection of Mycoplasma bovis in preservative treated field milk samples. J. Dairy Sci. 84(7):1640-1645.

POVEDA J.B., NICHOLAS R. 1998. Serological identification of mycoplasmas by growth and metabolic inhibition tests. In: Miles R.J., Nicholas R.A.J. (Eds.), Methods in Molecular Biology,. Mycoplasma Protocols. Vol 104. Humana Press, Totowa: 105-111
POVEDAJ.B. 1998. Biochemical characteristics in mycoplasma identification. In: Miles R.J., Nicholas R.A.J. (Eds.), Methods in Molecular Biology, Mycoplasma Protocols. Vol 104. Humana Press, Totowa: 69-78.

SUBRAMANIAM S., BERGONIER D., POUMARAT F., CAPAUL S., SCHLATTER Y., NICOLET J., FREY J. 1998. Species identification of Mycoplasma bovis and Mycoplasma agalactiae based on the uvrC genes by PCR. Mol. Cell. Probes. 12(3):161169.

TER LAAK E.A., NOORDERGRAAF J.H., BOOMSLUITER E. 1992. The nasal mycoplasmal flora of healthy calves and cows. J. Vet. Med. B. 39(8):610-616.

THIAUCOURT F., BOLSKE G., LENEGUERSH B., SMITH D., WESONGA H. 1996. Diagnosis and control of contagious caprine pleuropneumoniae. Rev. Sci. Tech. 15(4):1415-1429.

THOMAS A., BALL H., DIZIER I., TROLIN A., BELL C., MAINIL J., LINDEN A. 2002. Isolation of mycoplasma species from the lower respiratory tract of healthy cattle and cattle with respiratory disease in Belgium. Vet. Rec. 151: 472-476.

TOLA S., ANGIOI A., ROCCHIGIANI A. M., IDINI G., MANUNTA D., GALLERI G., LEORI G. 1997. Detection of Mycoplasma agalactiae in sheep milk samples by polymerase chain reaction. Vet. Microbiol. 54: 17-22.

VAN KUPPEVELD F.J., JOHANSSON K.E., GALAMA J.M., KISSING J., BÖLSKE G., VAN DER LOGT J.T., MELCHERS W.J. 1994.Detection of mycoplasma contamination in cell cultures by a mycoplasma group-specific PCR. Appl. Environ. Microbiol. 60:149-152. 